\title{
Sistem Informasi Pemberian Beasiswa Dana APBD Kota di SMP PGRI 3 Pangkalpinang
}

\author{
Yuyi Andrika ${ }^{\# 1}$, Enny Ningrum ${ }^{* 2}$ \\ \#Program Studi Sistem Informasi, STMIK Atma Luhur Pangkalpinang \\ Jln. Jend Sudirman Selindung Lama Pangkalpinang Propinsi Kepulauan Bangka Belitung \\ ${ }^{1}$ yuyiandrika@gmail.com \\ *STMIK Atma Luhur Pangkalpinang \\ Jln. Jend Sudirman Selindung Lama Pangkalpinang Propinsi Kepulauan Bangka Belitung \\ enningrum10@gmail.com
}

\begin{abstract}
Abstrak - SMP PGRI 3 Pangkalpinang merupakan instansi pendidikan menengah pertama, beralamatkan di Jalan Mustika II - Pangkalpinang Provinsi Kepulauan Bangka Belitung. Dalam penelitian sistem informasi proses pemberian beasiswa ini, ada beberapa sub bagian yaitu terdiri dari: Data Siswa, Daftar Pengajuan Beasiswa, Data Pemberitahuan Beasiswa, serta Laporan Beasiswa yang berhubungan dengan pengolahan data proses pemberian beasiswa. Metode menganalisa dan merancang sistem informasi menggunakan Unified Modelling Languange (UML) dan metode yang digunakan adalah metode berorientasi objek. Untuk implementasinya menggunakan bahasa pemograman Visual Basic 2008 dan Database Management Sistem menggunakan MySql. Penelitian ini juga bertujuan untuk pengelolaan pemberian beasiswa yang ada di SMP PGRI 3 dapat terorganisir dengan baik untuk penyimpanan datanya serta mempermudah dalam membuat surat pengajuan beasiswa, SK pemberian beasiswa dan laporan pemberian beasiswa.
\end{abstract}

Kata Kunci : SMP PGRI 3 Pangkalpinang , Sistem Informasi Proses Pemberian Beasiswa.

\section{Pendahuluan}

\section{A. Latar Belakang}

Dunia pendidikan semakin hari semakin berkembang. Pemerintah pun berupaya mengadakan program-program yang dinilai mampu untuk meningkatkan kualitas pendidikan di Indonesia terutama. Satu diantara dalam rangka meningkatkan kualitas pendidikan di Indonesia dengan mengadakan program pemberian beasiswa berdasarkan jenisnya seperti Beasiswa Kurang Mampu (BKM), Beasiswa Prestasi dan Bakat. Program Beasiswa bertujuan untuk meringankan beban orang tua siswa dalam membiayai pendidikan anaknya untuk wajib belajar 12 tahun. Berdasar pada keberadaan sistem pendidikan nasional adalah UUD 45 Bab XIII, Pasal 31, ayat (1) Yang menyatakan bahwa: Tiap-tiap warga negara berhak mendapatkan pengajaran.
Program Beasiswa dimulai pertahun ajaran baru yang merupakan salah satu program anggaran Kementerian Pendidikan Negara Republik Indonesia yang setiap tahun diadakan melalui lembaga pendidikan negeri dan swasta.

SMP PGRI 3 Pangkalpinang merupakan satu dari sekian banyak sekolah di Kota Pangkalpinang yang menerima bantuan dari dana APBD Kota. Dalam pelaksanaannya, pengelola dana bantuan beasiswa pada SMP PGRI 3 Pangkalpinang sering mengalami kesulitan dalam pencarian data siswa. SMP PGRI 3 Pangkalpinang selalu menghasilkan data dan informasi berbentuk laporan yang mana menggunakan aplikasi Microsoft Excel untuk meng-input data siswa untuk dijadikan sebuah laporan pendataan beasiswa dan saat ini masih dilakukan dengan cara manual sehingga mengakibatkan proses pengajuan yang cukup lama serta kurang efektif dimana dalam penyeleksian berkas persyaratan secara manual butuh waktu lebih dalam melakukan prosesnya. Terlebih lagi proses pengajuan yang masih bersifat manual masih terbatas pada lingkup ruang dan waktu.Adanya aplikasi yang sesuai maka pekerjaan yang sulit dapat dikerjakan secara mudah dengan bantuan teknologi informasi. Banyak keuntungan dan kelebihan yang ditawarkan sebuah aplikasi dalam pemanfaatan yang efektif, karena dapat mencapai hasil yang cepat, akurat, dan efesiensi karena dapat menghemat waktu dan tenaga sehingga pekerjaan apapun dapat dikerjakan dengan mudah dan tidak ada kesulitan dalam melakukan pekerjaan tersebut.

Aplikasi yang akan dibangun diharapkan agar dapat membantu serta mempermudah sistem kerja bagian tata usaha dalam melakukan proses administrasi atau pendataan setiap siswa dalam proses penerimaan beasiswa.

\section{TINJAUAN PUSTAKA}

\section{A. Pengertian Sistem}

Menurut [1] secara sederhana, sistem dapat diartikan sebagai suatu kumpulan atau himpunan dari unsur, komponen, atau variabel yang teroganisie, saling 
berinteraksi, saling bergantung satu sama lain dan terpadu.

\section{B. Pengertian Informasi}

Menurut [1] informasi merupakan proses lebih lanjut dari data yang sudah memiliki nilai tambah.

\section{Pengertian Sistem Informasi}

Sistem informasi terdiri dari komponen-komponen yang disebut blok bangunan yang terdiri dari blok masukan, blok model, blok keluaran, blok teknologi, blok basisdata dan blok kendali menurut [1].

\section{Unified Modelling Languange (UML)}

Merupakan bahasa yang berdasarkan grafik atau gambar untuk visualisai, spesifikasi, membangun dan mendokumentasi sistem informasi berbasis objek. Alat bantu yang digunakan dalam berorientasi objek antara lain [2] :

1) Activity diagram

2) Use Case diagram

3) Sequence Diagram

\section{E. Perancangan Berorientasi Objek}

Perancangan berorientasi objek bertujuan untuk :

1). Sistematika proses desain.

2). Menghasilkan desain model program.

3). Memberi gambaran masukan dengan efektif.

Menurut [3] Entity Relationship Diagram (ERD) merupakan hasil dari proses analisis terhadap sistem yang ditinjau oleh seorang analis sistem menurut [4].

\section{Metodologi Penelitian}

Metode pengumpulan data yang dilakukan dalam mendapatkan data tentang administrasi Proses Pemberian Beasiswa di SMP PGRI 3 Pangkalpinang adalah sebagai berikut :

\section{A. Analisa Masalah Dan Studi Kelayakan}

Pengumpulan data dengan cara dibawah ini :

1) Tinjauan Lapangan

Mengumpulkan data yang diperoleh langsung dari hasil penelitian pada SMP PGRI 3 Pangkalpinang, tinjauan lapangan dilakukan dengan tiga cara, yaitu :

a) Observasi (Pengamatan)

Melalui observasi lapangan dengan cara melihat secara langsung terhadap pelaksanaan kegiatan administrasi pada prose pemberian besiswa yang ada di SMP PGRI 3 Pangkalpinang. Berkenaan dengan proses administrasi proses pemberian beasiswa jangka pendek yang mempelajari bentuk dokumen-dokumen yang digunakan serta laporan yang dihasilkan untuk mengumpulkan data yang dibutuhkan. Adapun dokumen yang dipelajari dan dipahami adalah buku induk siswa, surat usulan beasiswa, surat pengajuan beasiswa, surat pemberitahuan beasiswa, sk beasiswa dan laporan beasiswa. b) Wawancara (interview)

Melalui wawancara langsung dengan pegawai bagian Tata Usaha di SMP PGRI 3 Pangkalpinang serta mengajukan pertanyaanpertanyaan pada pegawai bagian Tata Usaha yang terkait dengan alur permasalahan administrasi Proses Pemberian Beasiswa jangka pendek.

c) Penelitian Kepustakaan

Penelitian juga menggunakan berbagai sumber bacaan baik dari buku-buku ilmiah dan hasil pencarian di internet.

2) Untuk menggambarkan sistem yang sedang berjalan di SMP PGRI 3 pangkalpinang disini penulis menggunakan diagram activity untuk proses yang ada.

\section{B. Rancangan Sistem}

Alat-alat yang digunakan pada tahap perancangan sistem informasi ini antara lain sebagai berikut :
a. Class Diagram
b. Graphical User Interface (GUI)

\section{HASIL DAN PEMBAHASAN}

Prosedur yang dilakukan dalam Sistem Informasi Administrasi Proses Pemberian Beasiswa di SMP PGRI 3 Pangkalpinang adalah seperti terlihat pada Gambar 1.

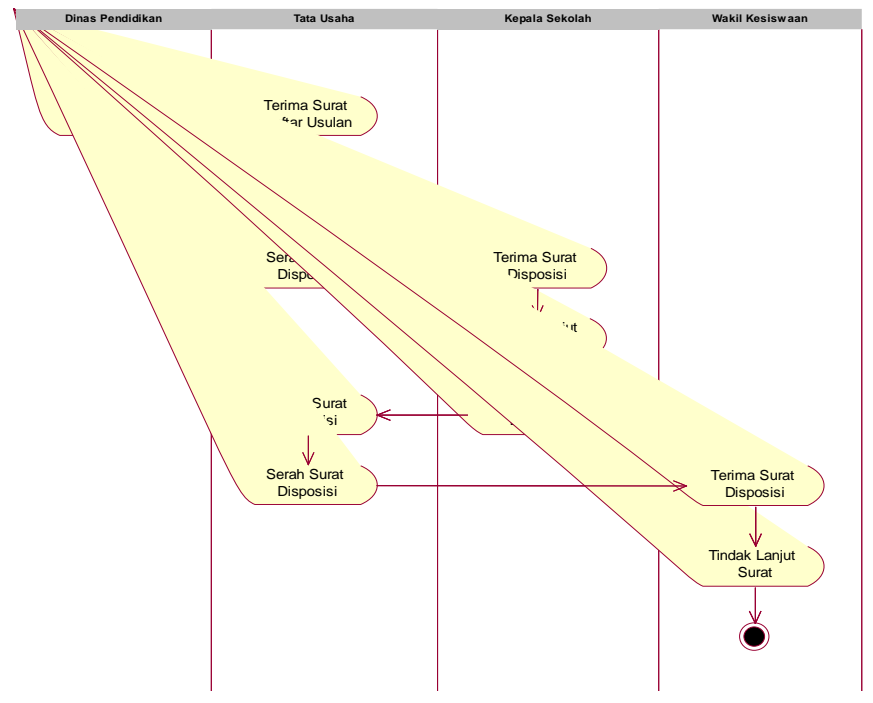

Gambar 1. Proses daftar usulan beasiswa

Dari gambar 2 dapat dijelaskan prosesnya sebagai berikut : Dinas pendidikan mengirimkan daftar usulan beasiswa ke tata usaha selanjutnya didisposisi ke kepala sekolah yang hasil disposisinya diserahkan tata usaha ke wakil kepala sekolah bagian kesiswaan untuk dilanjutkan. 


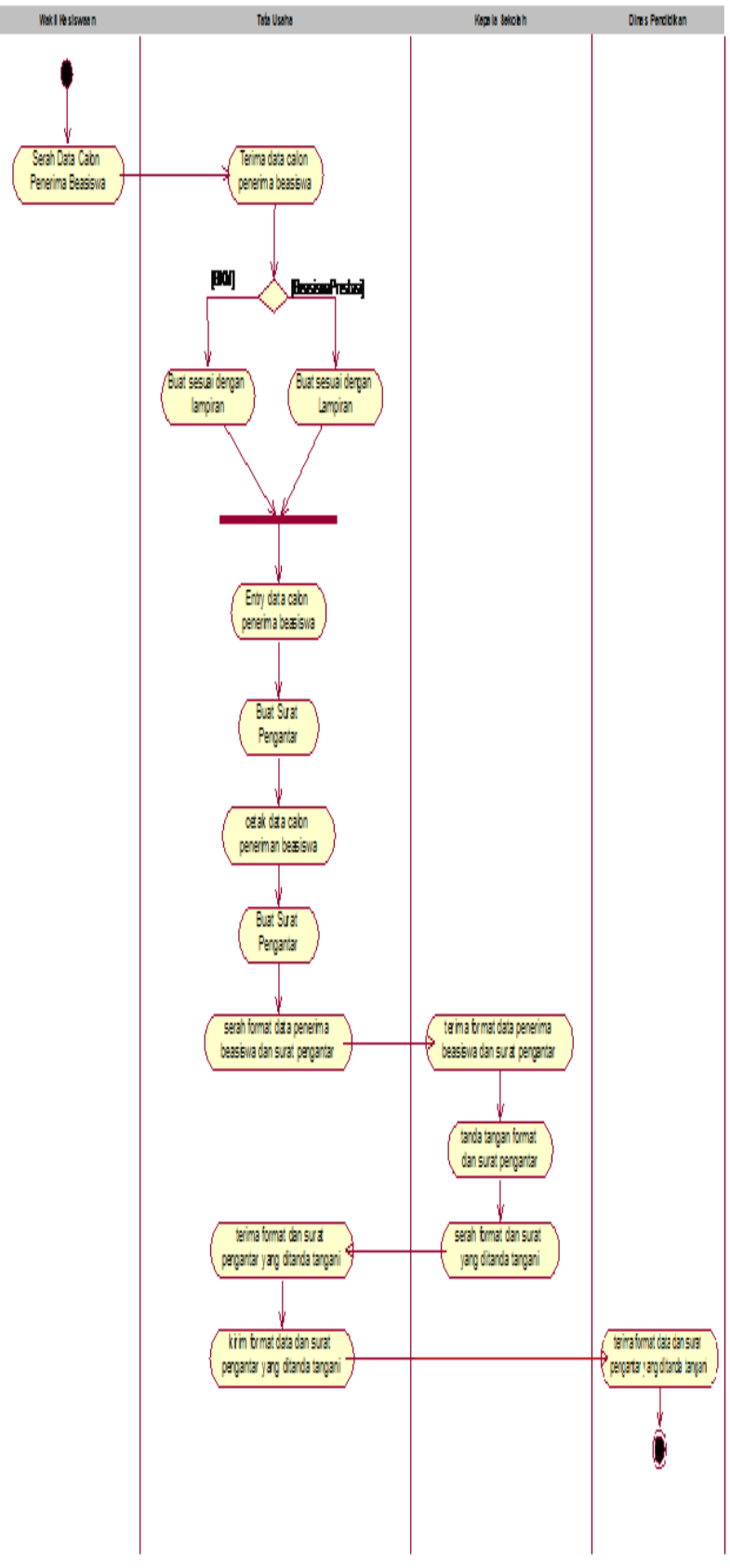

Gambar 2. Proses pengajuan penerima beasiswa

1) Proses untuk gambar 2 adalah :

Setelah didata siswa yang berhak maka TU akan membuatkan pengajuan penerimaan beasiswa yang ada sesuai format lampiran sesuai dengan kategori beasiswanya untuk beasiswa kurang mampu akan dimasukkan ke formulirnya sedangkan beasiswa prestasi akan dimasukkan ke formulir beasiswa prestasi. Setelah selesai pendataan beasiswanya maka TU akan membuatkan surat pengantar yang keduanya ditandatangani oleh kepala sekolah dan keduanya akan diserahkan ke Dinas Pendidikan.
Berdasarkan proses bisnis yang sudah dibuat, maka dapat dilihat basisdata untuk sistem informasi beasiswa dana APBD sebagai berikut

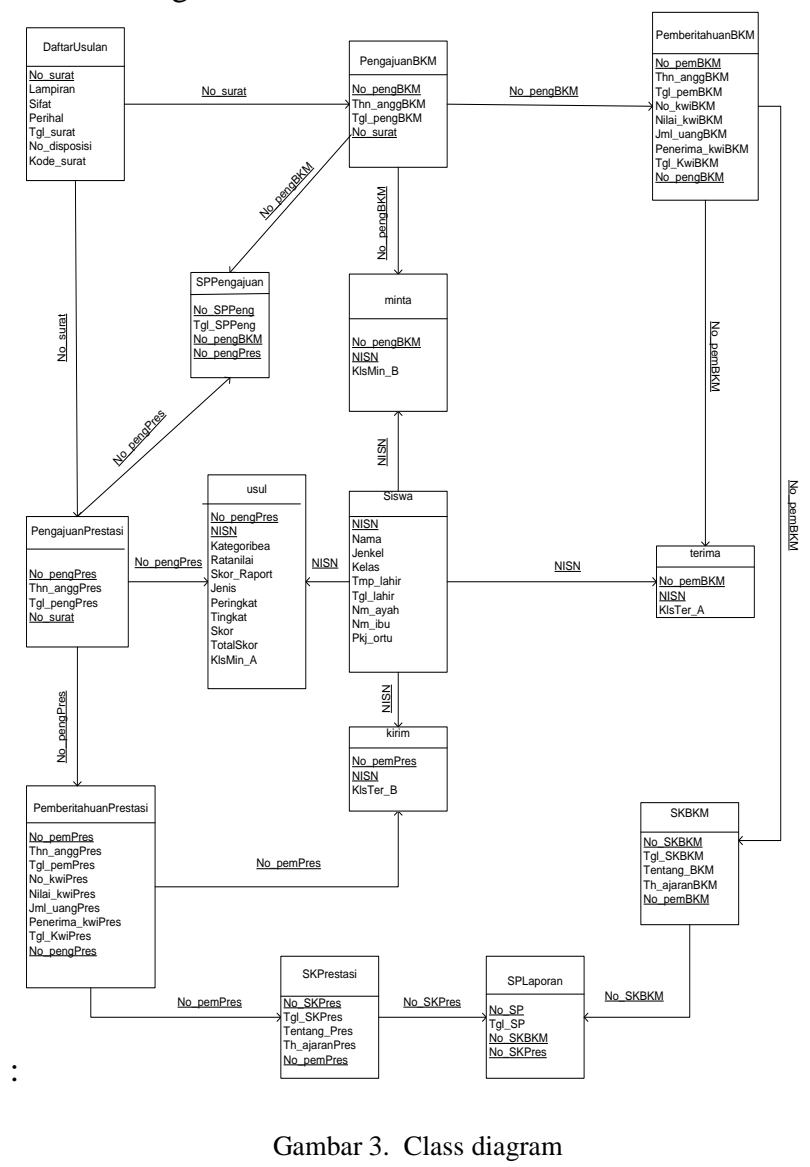

1) Dari basisdata yang digambarkan maka akan menghasilkan 14 tabel untuk menyimpan masing masing data dimana tabel yang dihasilkan adalah :

a) Tabel daftar usulan untuk menyimpana data usulan beasiswa dari dinas pendidikan.

b) Tabel PengajuanBKM untuk menyimpan pengajuan beasiswa kurang mampu.

c) Tabel minta untuk menyimpan kelas siswa yang memperoleh beasiswa.

d) Tabel PemberitahuanBKM untuk menyimpan data persetujuan beasiswa kurang mampu.

e) Tabel Pengajuanprestasi untuk menyimpan pengajuan beasiswa prestasi.

Serta tabel - tabel yang lainnya sesuai dengan masing - masing datanya, dimana satu kotak class diagram akan menghasilkan satu tabel.

\section{Pengujian}

Pengujian merupakan salah satu hal yang sangat penting dalam pengembangan sistem informasi. Pengujian untuk melihat efektif dan efesiensi sistem informasi. Tujuan dari pengujian sistem informasi yang dibangun agar berkualitas. Pengujian ini menggunakan black box. Pengujian Sistem Informasi Pemberian Beasiswa Dana 
APBD kota di SMP N 3 Pangkalpinang diuji dengan melihat pengentrian data yang dilakukan oleh staff administrasi SMP N 3 Pangkalpinang.

TABEL I

PENGUJIAN LAYAR ENTRY DATA SISWA

\begin{tabular}{|c|l|l|l|}
\hline No & $\begin{array}{c}\text { Requirement } \\
\text { yang diuji }\end{array}$ & \multicolumn{1}{|c|}{ Butir uji } & $\begin{array}{c}\text { Jenis } \\
\text { pengujian }\end{array}$ \\
\hline 1 & Simpan siswa & $\begin{array}{l}\text { User } \\
\text { melakukan } \\
\text { penyimpanan } \\
\text { data siswa }\end{array}$ & Black Box \\
\hline 2 & Ubah siswa & $\begin{array}{l}\text { User } \\
\text { melakukan } \\
\text { ubah data siswa }\end{array}$ & Black Box \\
\hline 3 & Hapus siswa & $\begin{array}{l}\text { User } \\
\text { melakukan } \\
\text { hapus } \\
\text { siswa data }\end{array}$ & Black Box \\
\hline
\end{tabular}

TABEL II

PENGUJIAN LAYAR ENTRY USULAN BEASISWA

\begin{tabular}{|c|l|l|l|}
\hline No & $\begin{array}{l}\text { Requirement } \\
\text { yang diuji }\end{array}$ & \multicolumn{1}{|c|}{ Butir uji } & $\begin{array}{c}\text { Jenis } \\
\text { pengujian }\end{array}$ \\
\hline 1 & $\begin{array}{l}\text { Simpan data } \\
\text { usulan } \\
\text { beasiswa }\end{array}$ & $\begin{array}{l}\text { User } \\
\text { melakukan } \\
\text { penyimpanan } \\
\text { data usulan } \\
\text { beasiswa }\end{array}$ & Black Box \\
\hline 2 & $\begin{array}{l}\text { Ubah data } \\
\text { usulan } \\
\text { beasiswa }\end{array}$ & $\begin{array}{l}\text { User } \\
\text { melakukan } \\
\text { ubah } \\
\text { usulan data } \\
\text { beasiswa }\end{array}$ & Black Box \\
\hline
\end{tabular}

TABEL III

PENGUJIAN LAYAR CETAK PENGAJUAN BEASISWA

\begin{tabular}{|c|l|l|l|}
\hline No & $\begin{array}{l}\text { Requirement } \\
\text { yang diuji }\end{array}$ & \multicolumn{1}{|c|}{ Butir uji } & \multicolumn{1}{c|}{$\begin{array}{c}\text { Jenis } \\
\text { pengujian }\end{array}$} \\
\hline 1 & $\begin{array}{l}\text { Cari data } \\
\text { usulan } \\
\text { beasiswa }\end{array}$ & $\begin{array}{l}\text { User } \\
\text { melakukan } \\
\text { pencarian data } \\
\text { usulan } \\
\text { beasiswa }\end{array}$ & Black Box \\
\hline 2 & $\begin{array}{l}\text { Cari data } \\
\text { siswa yang } \\
\text { dapat } \\
\text { beasiswa }\end{array}$ & $\begin{array}{l}\text { User } \\
\text { melakukan } \\
\text { pencarian data } \\
\text { siswa yang } \\
\text { dapat beasiswa }\end{array}$ & Black Box \\
\hline 3 & $\begin{array}{l}\text { Tambah data } \\
\text { siswa }\end{array}$ & $\begin{array}{l}\text { User } \\
\text { menambah data } \\
\text { siswa yang } \\
\text { dapat beasiswa }\end{array}$ & Black Box \\
\hline 4 & $\begin{array}{l}\text { Cetak } \\
\text { pengajuan } \\
\text { beasiswa }\end{array}$ & $\begin{array}{l}\text { User mencetak } \\
\text { form pengajuan } \\
\text { beasiswa }\end{array}$ & Black Box \\
\hline
\end{tabular}

A. Hasil pengujian
Berikut hasil pengujian dari Sistem Informasi Pemberian Dana APBD Kota di SMP Negeri 3 Pangkalpinang :

1. Pengujian semua pada proses dan setelah entri data siswa.

TABEL IV

PENGUJIAN LAYAR ENTRY DATA SISWA

\begin{tabular}{|c|c|c|c|}
\hline Requirement & $\begin{array}{c}\text { Skenario } \\
\text { uji }\end{array}$ & $\begin{array}{l}\text { Hasil yang } \\
\text { diharapkan }\end{array}$ & $\begin{array}{c}\text { Hasil } \\
\text { penguji } \\
\text { an }\end{array}$ \\
\hline \multirow[t]{2}{*}{ Simpan siswa } & $\begin{array}{l}\text { Simpan } \\
\text { siswa } \\
\text { (jika data } \\
\text { benar) }\end{array}$ & $\begin{array}{l}\text { Data akan } \\
\text { tersimpan ke } \\
\text { database } \\
\text { yaitu ke tabel } \\
\text { siswa }\end{array}$ & Sesuai \\
\hline & $\begin{array}{c}\text { Simpan } \\
\text { siswa } \\
\text { (jika data } \\
\text { salah) }\end{array}$ & $\begin{array}{l}\text { Tampil } \\
\text { peringatan } \\
\text { untuk } \\
\text { memperbaiki } \\
\text { data yang } \\
\text { inputannya } \\
\text { salah }\end{array}$ & Sesuai \\
\hline \multirow[t]{2}{*}{ Ubah siswa } & $\begin{array}{c}\text { Ubah } \\
\text { data } \\
\text { siswa } \\
\text { (jika data } \\
\text { benar) }\end{array}$ & $\begin{array}{l}\text { Field yang } \\
\text { diubah } \\
\text { datanya akan } \\
\text { berubah dan } \\
\text { tersimpan di } \\
\text { tabel siswa }\end{array}$ & Sesuai \\
\hline & $\begin{array}{c}\text { Ubah } \\
\text { data } \\
\text { siswa } \\
\text { (jika data } \\
\text { salah) }\end{array}$ & $\begin{array}{l}\text { Field yang } \\
\text { diubah } \\
\text { datanya tidak } \\
\text { akan berubah } \\
\text { daan akan } \\
\text { memunculkan } \\
\text { konfirmasi } \\
\text { kesalahan }\end{array}$ & Sesuai \\
\hline \multirow[t]{2}{*}{ Hapus siswa } & $\begin{array}{c}\text { Hapus } \\
\text { data (jika } \\
\text { data } \\
\text { benar) }\end{array}$ & $\begin{array}{l}\text { Data akan } \\
\text { terhapus ke } \\
\text { database } \\
\text { yaitu ke tabel } \\
\text { siswa }\end{array}$ & Sesuai \\
\hline & $\begin{array}{c}\text { Hapus } \\
\text { data (jika } \\
\text { data } \\
\text { salah) }\end{array}$ & $\begin{array}{lr}\text { Data akan } \\
\text { terhapus dari } \\
\text { database } \\
\text { yaitu dari } \\
\text { tabel siswa } \\
\end{array}$ & Sesuai \\
\hline
\end{tabular}

2. Pengujian semua proses pada proses dan setelah dientri usulan beasiswa 
TABEL V

PENGUJIAN LAYAR ENTRY USULAN BEASISWA

\begin{tabular}{|c|c|c|c|}
\hline $\begin{array}{c}\text { Requirem } \\
\text { ent }\end{array}$ & $\begin{array}{c}\text { Skenario } \\
\text { uji }\end{array}$ & $\begin{array}{l}\text { Hasil yang } \\
\text { diharapkan }\end{array}$ & $\begin{array}{c}\text { Hasil } \\
\text { pengujian }\end{array}$ \\
\hline \multirow[t]{2}{*}{$\begin{array}{l}\text { Simpan } \\
\text { data usulan } \\
\text { beasiswa }\end{array}$} & $\begin{array}{c}\text { Simpan } \\
\text { data usulan } \\
\text { beasiswa } \\
\text { (jika data } \\
\text { benar) }\end{array}$ & $\begin{array}{l}\text { Data akan } \\
\text { tersimpan ke } \\
\text { database } \\
\text { yaitu ke } \\
\text { tabel } \\
\text { daftarusulan }\end{array}$ & Sesuai \\
\hline & $\begin{array}{c}\text { Simpan } \\
\text { data usulan } \\
\text { beasiswa } \\
\text { (jika data } \\
\text { salah) }\end{array}$ & $\begin{array}{l}\text { Tampil } \\
\text { peringatan } \\
\text { untuk } \\
\text { memperbaiki } \\
\text { data yang } \\
\text { inputannya } \\
\text { salah }\end{array}$ & Sesuai \\
\hline \multirow[t]{2}{*}{$\begin{array}{l}\text { Ubah data } \\
\text { usulan } \\
\text { beasiswa }\end{array}$} & $\begin{array}{l}\text { Ubah data } \\
\text { usulan } \\
\text { beasiswa } \\
\text { (jika data } \\
\text { benar) }\end{array}$ & $\begin{array}{l}\text { Field yang } \\
\text { diubah } \\
\text { datanya akan } \\
\text { berubah dan } \\
\text { tersimpan di } \\
\text { tabel } \\
\text { daftarusulan }\end{array}$ & Sesuai \\
\hline & $\begin{array}{c}\text { Ubah data } \\
\text { data usulan } \\
\text { beasiswa } \\
\text { (jika data } \\
\text { salah) }\end{array}$ & $\begin{array}{l}\text { Field yang } \\
\text { diubah } \\
\text { datanya } \\
\text { tidak akan } \\
\text { berubah dan } \\
\text { akan } \\
\text { memunculka } \\
\text { n konfirmasi } \\
\text { kesalahan } \\
\end{array}$ & Sesuai \\
\hline
\end{tabular}

3. Pengujian semua proses pada proses dan setelah dientri usulan beasiswa.

TABEL VI

PENGUJIAN LAYAR CETAK PENGAJUAN BEASISWA

\begin{tabular}{|l|c|l|c|}
\hline \multicolumn{1}{|c|}{$\begin{array}{c}\text { Require } \\
\text { ment }\end{array}$} & $\begin{array}{c}\text { Skenario } \\
\text { uji }\end{array}$ & $\begin{array}{l}\text { Hasil yang } \\
\text { diharap } \\
\text { kan }\end{array}$ & $\begin{array}{c}\text { Hasil } \\
\text { pengu } \\
\text { jian }\end{array}$ \\
\hline $\begin{array}{l}\text { Cari data } \\
\text { usulan } \\
\text { beasiswa }\end{array}$ & $\begin{array}{c}\text { Cari data } \\
\text { usulan } \\
\text { (jika data } \\
\text { benar) }\end{array}$ & $\begin{array}{l}\text { Tampil } \\
\text { data usulan } \\
\text { beasiswa } \\
\text { yang dicari } \\
\text { dan tinggal } \\
\text { dipilih }\end{array}$ & Sesuai \\
\cline { 2 - 4 } & $\begin{array}{c}\text { Cari data } \\
\text { usulan } \\
\text { (jika data } \\
\text { salah) }\end{array}$ & $\begin{array}{l}\text { Tampil } \\
\text { pemberitah } \\
\text { uan data } \\
\text { tidak } \\
\text { ditemukan }\end{array}$ & Sesuai \\
\hline $\begin{array}{l}\text { Cari data } \\
\text { siswa yang } \\
\text { dapat } \\
\text { beasiswa }\end{array}$ & $\begin{array}{c}\text { Cari data } \\
\text { siswa } \\
\text { (jika data } \\
\text { benar) }\end{array}$ & $\begin{array}{l}\text { Tampil } \\
\text { data siswa } \\
\text { yang dicari } \\
\text { dan tinggal } \\
\text { dipilih }\end{array}$ & \\
\hline
\end{tabular}

\begin{tabular}{|c|c|c|c|}
\hline & $\begin{array}{l}\text { Cari data } \\
\text { siswa } \\
\text { (jika data } \\
\text { salah) }\end{array}$ & $\begin{array}{l}\text { Tampil } \\
\text { pemberitah } \\
\text { uan data } \\
\text { tidak } \\
\text { ditemukan }\end{array}$ & Sesuai \\
\hline \multirow[t]{2}{*}{$\begin{array}{l}\text { Tambah } \\
\text { data siswa }\end{array}$} & $\begin{array}{c}\text { Tambah } \\
\text { data (jika } \\
\text { data benar) }\end{array}$ & $\begin{array}{l}\text { Data akan } \\
\text { bertambah } \\
\text { ke form } \\
\text { cetak } \\
\text { pengajuan } \\
\text { beasiswa }\end{array}$ & Sesuai \\
\hline & $\begin{array}{c}\text { Tambah } \\
\text { data (jika } \\
\text { data salah) }\end{array}$ & $\begin{array}{l}\text { Data tidak } \\
\text { akan } \\
\text { bertambah } \\
\text { ke form } \\
\text { cetak } \\
\text { pengajuan } \\
\text { beasiswa }\end{array}$ & Sesuai \\
\hline \multirow[t]{2}{*}{$\begin{array}{l}\text { Cetak } \\
\text { pengajuan } \\
\text { beasiswa }\end{array}$} & $\begin{array}{c}\text { Cetak data } \\
\text { (jika data } \\
\text { benar) }\end{array}$ & $\begin{array}{l}\text { Data akan } \\
\text { tercetak ke } \\
\text { printer dan } \\
\text { data } \\
\text { pengajuan } \\
\text { akan } \\
\text { tersimpan } \\
\text { ke tabel } \\
\text { pengajuan } \\
\text { beasiswa }\end{array}$ & Sesuai \\
\hline & $\begin{array}{c}\text { Cetak data } \\
\text { (jika data } \\
\text { salah) }\end{array}$ & $\begin{array}{l}\text { Data tidak } \\
\text { akan } \\
\text { tercetak } \\
\text { dan tidak } \\
\text { akan } \\
\text { tersimpan }\end{array}$ & Sesuai \\
\hline
\end{tabular}

B. Tampilan layar untuk user beriteraksi dengan sistem informasi dapat dilihat dibawah ini :

1) Grapichal user interface untuk menu utama

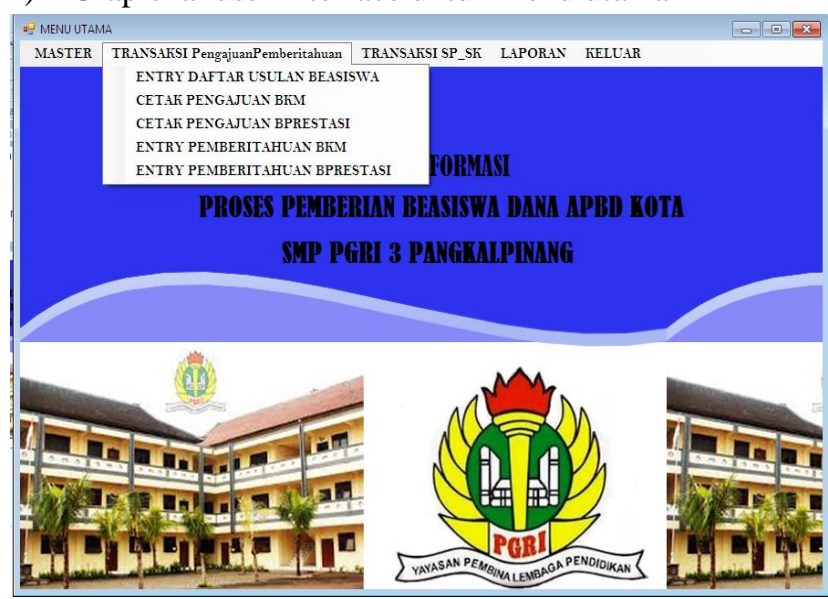

Gambar 4. Menu Utama

Gambar 4 menggambarkan transaksi yang terdapat di sistem informasi pemberian beasiswa di mana terdapat menu master yang didalamnya terdapat menu entry 
data siswa, menu transaksi pengajuanpemberitahuan yang didalamnya terdapat menu entry usulan beasiswa, cetak pengajuan beasiswa kurang mampu, cetak pengajuan beasiswa prestasi, entry penerima beasiswa kurang mampu dan yang terakhir adalah entry penerima beasiswa prestasi. Didalam menu transaksi SP dan SK terdapat menu cetak sk beasiswa kurang mampu, cetak sk beasiswa prestasi, cetak pengantar penngajuan beasiswa dan cetak laporan pengantar. Sedangkan di menu laporan akan terdapat menu cetak laporan beasiswa kurang mampu dan cetak laporan beasiswa prestasi.

2) Grapichal user interface untuk menu entry data siswa.

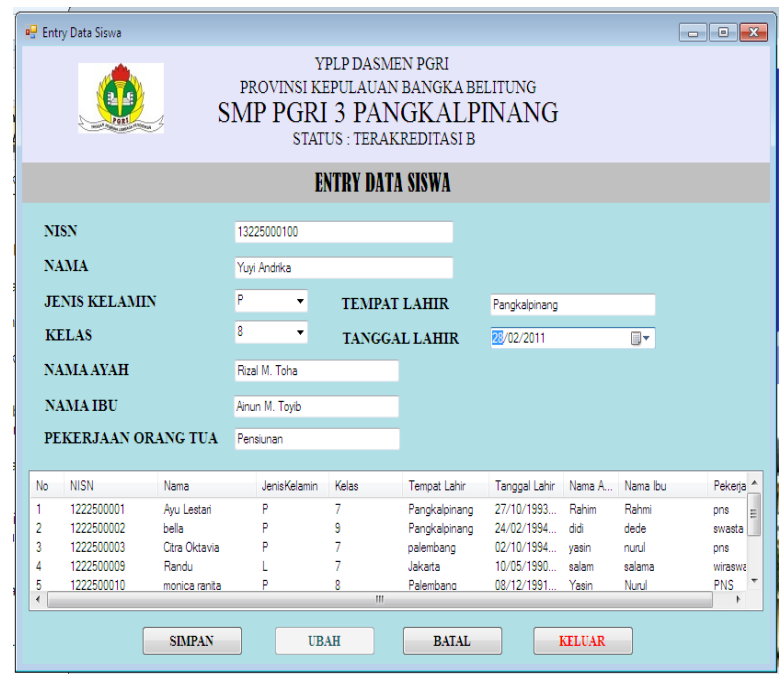

Gambar 5. Entry data siswa

Berdasarkan gambar diatas dapat dijelaskan prosesnya berikut ini :

Untuk menginput data siswa maka Tu akan memilih menu master selanjutnya memilih menu entry data siswa, setelah form terbuka maka TU akan menginput mulai dari NISN sampai PEKERJAAN ORANG TUA setelah selesai maka TU akan menyimpan data tersebut dengan cara memilih tombol SIMPAN dan apabila ada yang salah maka TU akan memilih tombol UBAH.

3) Grapichal user interface untuk menu entry daftar usulan beasiswa.

Urutan proses untuk gambar nomor 6 sebagai berikut : Bagian TU akan memilih menu ini didalam menu TransaksiPengajuanPemberitahuan selanjutnya TU akan menginput NO SURAT sampai dengan KODE SURAT dan memilih tombol SIMPAN apabila sudah selesai. Untuk keluar dari form TU akan pilih tombol KELUAR.
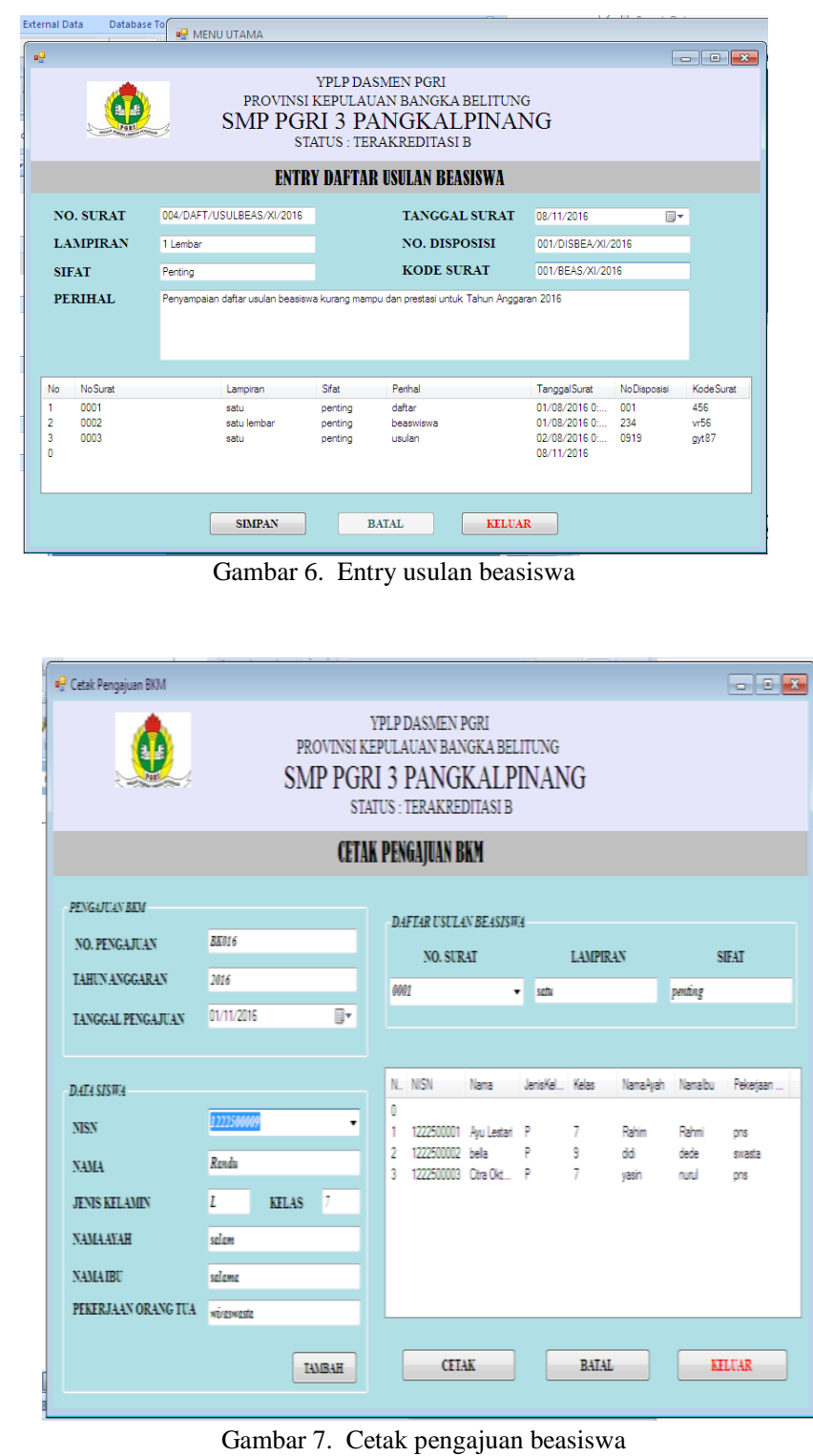

Proses untuk gambar 7 adalah sebagai berikut :

TU akan memilih menu ini di menu Transaksipengajuanpemberitahuan selanjutnya TU akan menginput NO PENGAJUAN sampai TANGGAL PENGAJUAN, selanjutnya TU akan memilih NO SURAT daftar usulan beasiswa maka LAMPIRAN dan SIFAT akan tampil. TU memilih NISN siswa yang akan diajukan untuk mendapatkan beasiswa maka NAMA sampai PEKERJAAN ORANG TUA akan tampil dan TU akan pilih tombol TAMBAH untuk menambah data siswa berikutnya karena di satu pengajuan akan muncul banyak siswa. Setelah menginput semua data maka TU akan pilih tombol CETAK untuk mencetak pengajuan BKM. 


\section{KESIMPULAN}

Kesimpulan yang berkaitan dengan Analisa dan Perancangan Sistem Informasi Proses Pemberian Beasiswa Dana APBD Kota di SMP PGRI 3 Pangkalpinang yaitu sebagai berikut:

a.Aplikasi Sistem Informasi Proses Pemberian Beasiswa yang berbasis VB.NET 2008, dapat memberikan kemudahan bagi Pegawai Tata Usaha dalam menyimpan, mengakses, dan mencari datadata siswa.

b. Dengan menggunakan sistem yang telah terkomputerisasi maka hasil pekerjaan akan lebih efisien dan efektif, dalam hal ini sistem yang sudah terkomputerisasi mempermudah pekerjaan.

c. Penyimpanan data dengan menggunakan sistem yang terkomputerisasi lebih aman dibandingkan dengan manual yang mana jika suatu saat dokumen asli mengalami kehilangan atau perubahan data, maka akan terjaga dokumen yang sudah menjadi database dan dengan praktis proses perubahan datanya.

d. Laporan Proses Pemberian Beasiswa dapat dibuat dengan mudah, cepat, dan akurat sehingga dapat disajikan dengan tepat waktu.

e. Dalam perancangan sistem ini, diharapkan dapat membantu meringankan pekerjaan yang ada di SMP PGRI 3 Pangkalpinang, baik penginputan, pencetakkan, pembuatan laporan serta sebagai media penyimpanan data.

\section{REFERENSI}

[1] Sutabri. Tata, Konsep Sistem Informasi, Yogyakarta, Andi, 2012.

[2] Munawar, Pemodelan Sistem dengan UML, Jakarta, Graha Ilmu, 2015.

[3] Whitten. Jeffrey, Metode Design dan Analisis Sistem Yogyakata, Andi, Edisi 6, 2004.

[4] Haryanto. Imam, Membuat Database dengan Microsoft Access, Bandung, Informatika Bandung, 2008. 